\title{
The Approach of Integrated Coastal Zone Management: From Technical to Political Point of View
}

\section{García-Sanabria, Javier ${ }^{*}$}

Faculty of Marine and Environmental Sciences, University of Cádiz, Spain

*Corresponding author: García-Sanabria Javier, Faculty of Marine and Environmental Sciences, University of Cadiz, Spain, Tel: +0034-652794836; E-mail: javier.sanabria@uca.es

Received date: March 16, 2015; Accepted date: March 18, 2015; Published date: March 25, 2015

Copyright: (2015 Javier GS. This is an open-access article distributed under the terms of the Creative Commons Attribution License, which permits unrestricted use, distribution, and reproduction in any medium, provided the original author and source are credited.

\section{Editorial}

The Integrated Coastal Zone Management (ICZM) is a technicalscientific discipline that has been internationally recognized as the most appropriate to address the sustainable management of coastal and marine areas [1]. Then it is convenient to use the inertia and experience generated by this discipline that has already defined a suitable framework for the management of coastal and marine areas.

ICZM should be conceived as an instrument designed to develop a coastal and marine policy $[2,1,3]$. This is a young discipline, and its origins seems to come from the US and Europe at the end of the sixties. In 1969 the explosion of an offshore oil well off the coast of California generated public concern that reinforced the campaign to approve the US coastal management Act [1]. Indeed, several authors [4-6,1] agree in indicating the US public policy document "Our nation and the sea, a plan for National Action" in 1969 as the main antecedent of the law "Coastal Zone Management Act" of 1972, which already has over 40 years of travel.

Since the late sixties to the present there have been several stages that have marked the evolution of coastal management. Different authors divided into 4 periods the development of ICZM [7-9,2].

In a first step that could be dated to the 60 s and 70 s of last century, the approach was to manage the predominant sectors. The idea of division of labour to increase efficiency in achieving results is what lies behind the widespread fragmentation of policies and institutional structures. This is a management way that arises from a purely economic and anthropocentric perspective of the use of resources and natural areas [7]. It is the heyday of "technocratic" and "developmental" planning, in which action in coastal areas is often limited to sporadic react to critical situations [2].

Important advances were given in the eighties. The environmental protection has emerged as reaction to environmental degradation. Consequently, the first performances of coastal protection were carried out but they were related to solving very specific problems, such as erosion of a coastline or pollution outfalls episodes, [3]. However, the most important advance came from the hand of complexity theory versus sectorial approach. Indeed, this theoretical development has enabled the interpretation of the coastline problems from a more global and encompassing vision [9]. The United Nations Conference held in Rio de Janeiro in 1992 reinforces this change of doctrine through the guidelines of Agenda 21 [10].

In the nineties there was a conceptual change characterized by the focus on sustainability and public participation; greater emphasis on the restoration and recovery of the environment after a disturbance; initiatives oriented towards the long term guided by the precautionary principle and the needs of present and future generations. Finally, in the nineties a change of great importance was given: there was a rapprochement between social-physical-natural sciences and decisionmaking process $[3,1]$.

In the first decade of XXI century ecosystem-based approach was consolidated, and it has been reflected in expanding the boundaries of the geographic scope of ICZM [3]. The new approach conceives the human being as part of ecosystems, forming central part of them. The relationship of ecosystem services to human welfare is emphasized and tools for coordination and cooperation, participation, transparency, public interest, etc, are sought in order to achieve the governance of these spaces. At the same time, the increasing interest in developing new uses and activities at sea brought an important concern about its environmental consequences. Problems between uses and activities started to arise, but also claims made by several countries were trying to expand national boundaries to huge marine areas beyond national jurisdictions. At the end of the first decade of XXI century United Nations reacts to this situation by developing a "Marine Spatial Planning" guide [11] trying to organize and orient all the different planning initiatives that many countries were developing at their national seas.

At this time many definitions have been proposed for ICZM by different authors and institutions [12-23,2,1]. Sometimes ICZM has been defined under different terms, although all agree in several principles. First, it has been almost unanimously interpreted as a process and, on the other hand, the integration has been directed towards finding a balance between environmental conservation and human welfare through appropriate public policies [5].

Furthermore, many of the proposed definitions include the marine environment, reaching some to incorporate it explicitly in the term. Others incorporate the marine areas implicitly by referring to littoral or coastal areas, which by definition also incorporate at least the nearest coastal marine area, precisely those most productive except in the case of upwelling zones. In fact, it is possible to observe the presence of the marine environment in most of the above definitions. Even it is clear a tendency to incorporate it with the evolution of the discipline. There is therefore a growing concern about the management of the marine environment from the integrated management of coastal areas. In this sense, "Marine Spatial Planning" should be seen as a tool for ICZM in the nearest shore waters [24-26].

Among the several ICZM approaches appear interpretations that identify it with the management of natural resources, the search for models of development, conflict resolution, etc. At present it seems that the approximation of Ecosystem Based Management (EBM Ecosystem Based Management or) is consolidated. According to [23] in this conception, the human being is an integral and central part of the ecosystem. Indeed when ecosystems are assessed, they are not only 
evaluated in terms of environmental processes, but also are interpreted the ecosystem services they provide to human wealth. In any case the EBM "intends to organize human uses of ecosystems to achieve a balance between the benefits of natural resources made available by the elements and processes of an ecosystem, while this capacity is maintained to provide those at a sustainable level."

Significantly, when the UNEP [23] contrasts coastal-marine Ecosystem-Based Management (EBM) with ICZM, acknowledges, with some caveats, proximity and similarity between two concepts.

Besides international references, there are countries that have adopted a singular vision of ICZM concept. Indeed, in Germany ICZM is seen as a process in planning and decision making but also as a philosophy [27]. The latter is a more open approach; made from a number of basic principles that serve as benchmarks. In this case these principles provide a considerable degree of flexibility, for example, address a national strategy which, in turn, would take into account regional specific conditions and new conditions that suddenly can appear. By agreeing to these basic principles, that would be the first task in the process of ICZM, it is also possible to find common agreement issues between different institutions, interest groups, administrative levels and sectors working on the coast [28].

Another country that defines ICZM in its institutional policy documents is Canada [29]. It does this through three complementary interpretations of ICZM:

- As a comprehensive approach to plan and manage human activities so that some do not conflict with each other, in a way that all factors are being considered for conservation and sustainable use.

- As a collaborative approach which cannot be forced by anyone.

- As a process of flexible and transparent planning that respects existing divisions of constitutional and departmental authority, and does not override existing treaties of the native population.

Any ICZM initiative implies to recognize and accept a number of basic premises which are manifested in a number of principles. Several authors and institutions have developed proposals in this regard [30-32]. All of them highlight the need for holistic and participatory approach, and the need for coordination and adaptive management to changes that continually arise in coastal areas.

In any case, what is clear is that any ICZM initiative must emphasize principles regarding voluntariness, flexibility, coordination between institutions and territorial levels of management, cooperation between the public sector and non-governmental, democratic legitimacy involving public participation, etc. Therefore, if the idea is to achieve an integrated coastal zone management, further efforts should be directed to the field of public policy. And this because the problems of achieving an ICZM are, mostly of the times, not in the scientifictechnic realm, neither in the lack of information for managing, on the contrary, they are in the lack of will, leadership, coordination, public participation and so on. In conclusion, one of the biggest goals is making the ICZM becomes a public policy within a governance framework.

\section{References}

1. Barragán JM (2014) Política, gestión y litoral. Una nueva visión de la gestión integrada de áreas litorales. UNESCO y Editorial Tébar 620; 978: 518-512.
2. Barragán JM (2003) Medio ambiente y desarrollo en áreas litorales. Introducción a la Planificación y Gestión Integradas. Servicio de publicaciones 301 .

3. Pérez-Cayeiro ML (2013) Gestión Integrada de Áreas Litorales. Análisis de los fundamentos de la disciplina. Ed Tébar Madrid 404.

4. Arenas Granados P (2010) Manejo costero integrado y sustentabilidad: un análisis pro-positivo de políticas públicas en las dos caras atlánticas (España- Portugal y Co-lombia- Panamá). Tesis doctoral. 414.

5. 5. Pérez-Cayeiro ML (2012) Gestión Integrada de Áreas Litorales. Evolución de la disciplina en las últimas dos décadas. Tesis Doctoral 475.

6. Sorensen JC (1990) Coastal Zone Management. Techniques and instruments. Massachusetts University, Postgraduate Course.

7. Martins FM (1997) Políticas de Planeamiento, Ordenamiento e Gestao Costei-ra. Contributo para uma discussao metodológica. Tesis Doctoral. Departamento de Ambiente e Ordenamento. Universidade de Aveiro. Aveiro 270.

8. Kay R, Alder J (1999) Coastal planning and management. E\&FN Spon 370.

9. Vallega A (1999) Fundamentals of integrated Coastal Management. Kluwer Academic Publishers 264.

10. UNCED (1993) United Nations Conference on Environment and Development. Río de Janeiro, June 1992. Important results of UNCED were: Rio Declaration, Agenda 21, Convention on Biological Diversity, Framework Convention on Climate Change.

11. Ehler C, Douvere F (2009) Marine Spatial Planning: A step-by-step approach toward Ecosystem-based Management. Intergovernmental Oeanographic Commision. Manual and Guides.

12. Clark JR (1992) Integrated management of coastal zones. FAO Fisheries Technical Paper 327: 167.

13. PNUMA (1993) Directrices para una planificación y un manejo integrado de las áreas costeras y marinas en la región del Gran Caribe.

14. Carvallo VC, Rizzo HG (1994) A zona costeira brasileira. Subsídios para uma avaliaçâo ambiental. Ministerio de Medio Ambiente y de la Amazonia. Secretaría de coordinación de asuntos de Medio Ambiente.

15. OCDE (1995) Gestión de Zonas Costeras. Políticas Integradas. Ediciones Mundi Prensa. Madrid. 204.

16. UNEP (1995) Guidelines for Integrated Management of Coastal and Marine Areas. UNEP Regional Seas Reports and Studies 161: 80.

17. European Commission (EC) (1999) Lessons from the European Commission's demonstration programme on Integrated Coastal Zone Management (ICZM).

18. Council of Europe (2000) Model Law on Sustainable Management of Coastal Zones. Strasbourg, Council of Europe Publishing, Nature and Environmental Series 101: 27.

19. Convention of Biodiversity (CBD) (2004) Integrated Marine and Coastal Area Management (IMCAM) approaches for implementing the Convention on Biological Diversity. CBD Technical Series. 14: 51.

20. Castro C, Morales E (2006) La zona costera. Medio Natural y Ordenación Integrada. Santiago de Chile. Pontificia Universidad Católica de Chile. Santiago de Chile. 210.

21. Suárez de Vivero JL (2007) Atlas de la Europa marítima. Jurisdicciones, usos y gestión, Ed El Serbal Barcelona 156.

22. Pnuma, Claes, Dinama (2008) Programa de Naciones Unidas para el Medio Ambiente, Centro Latino Americano de Ecologia Social y Dirección Nacional de Medio Ambiente. GEO Uruguay. Informe del estado del ambiente. PNUMA Oficina Regional para América Latina y el Centro Latino Americano de Ecología Social 350.

23. United National Environment Programme (UNEP) (2011) Taking Steps toward Marine and Coastal Ecosystem- based Management. An introductory guide. UNEP Regional Seas Reports and Studies 189: 67.

24. García-Sanabria J (2014) The Scope of Marine Spatial Planning and Integrated Coastal Zone Management: New Challenges for the Future. J Coast Dev 17: 109. Doi: 10.4172/1410-5217.1000e109

25. García-Sanabria J (2014) La planificación espacial marina: una herramienta útil para diferentes ámbitos de aplicación. Actas del VII Congreso Internacional de Ordenación del Territorio. 212-226. 
Citation: Javier GS (2015) The Approach of Integrated Coastal Zone Management: From Technical to Political Point of View. J Coast Zone Manag 18: e111. doi:10.4172/2473-3350.1000e111

Page 3 of 3

26. García-Sanabria J, Arenas Grandos P, Arcila Garrido M (2015) La gestión del medio marino: el sistema costero-marino. Agali-Journal.

27. Bundesministerium für Verkehr, Bau und Stadtentwicklung (BMVBS) (2006) Integrated Coastal Zone Management (ICZM): Strategies for coastal and marine spatial planning. Final report. The role of spatial planning and ICZM in the sustainable development of coastal and seas. Berlin 76.

28. Barragán JM, Chica JA, Pérez-Cayeiro ML (2011) Gestión integrada de áreas litorales en España, Biodiversidad en España. Base de la sostenibilidad ante el cambio global. Observatorio de la Sostenibilidad en España 2011: 380-389

29. Fisheries and Oceans Canada (2002) Canada's Oceans Strategy. Our Oceans, Our Future. Policy and operational framework for integrated management of estuarine, coastal and marine environments in Canada. Govermment of Canada 36.

30. Food and Agriculture Organization of the United Nations (FAO) (1992) Integrated management of coastal zones Fisheries Technical Paper 327.

31. European Commission (EC) (2002) Communication from the Commission to the Council and the European Parliament: Towards a strategy to protect and conserve the marine environment. COM 539.

32. García-Sanabria J, García-Onetti J, Barragán JM (2011) Las Comunidades Autónomas y la gestión integrada de las áreas litorales en España. Materiales para un debate sobre gobernanza. Fundación Biodiversidad y Universidad de Cádiz, 220 